\title{
An in vivo study regarding analgesic and anxiolytic activity of methanolic extract of Typha elephantina Roxb
}

\author{
Niloy Sen ${ }^{1 *}$ (D, Latifa Bulbul ${ }^{1}$, Md. Saddam Hussain ${ }^{1}$, Sujan Banik ${ }^{1}$ and Md. Shahbuddin Kabir Choudhuri
}

\begin{abstract}
Background: Typha elephantina Roxb. is a widely scattered grass like medicinal plant in Bangladesh and thus demands biological investigations to discover its therapeutic potentiality. The aim of our present study was to assess analgesic and anxiolytic properties of methanolic extract of Typha elephantina Roxb.
\end{abstract}

Methods: For evaluating analgesic activity, the methanolic extract was subjected to intraperitoneally (i.p.) administered acetic acid-induced writhing test \& subcutaneously administered (s.c.) formalin-induced hind paw licking test in Swiss-albino mice. The anxiolytic activity was conducted by using elevated plus maze (EPM) and hole board models.

Results: For both methods of analgesic test experimental plant extract was found to have significant $(p<0.001)$ analgesia at the dose of $200 \mathrm{mg} / \mathrm{kg} \& 400 \mathrm{mg} / \mathrm{kg}$ body weight in mice when compared to control, where acetyl salicylic acid (100 mg/kg body weight) was used as standard drug. The percentages of inhibition found in case of acetic acid-induced writhing test were $26.27 \%, 50.45 \%$ and $20.29 \%$ respectively for acetyl salicylic acid $(100 \mathrm{mg} / \mathrm{kg}), 200 \mathrm{mg} / \mathrm{kg}$ extract dose and $400 \mathrm{mg} / \mathrm{kg}$ extract dose. On the other hand, during formalin-induced hind paw licking test, the percentages of inhibition also increased when the extract dose increases from $200 \mathrm{mg} / \mathrm{kg}$ to $400 \mathrm{mg} / \mathrm{kg}$ by $53.95 \%$ to $61.79 \%$ at early phase and $71.62 \%$ to $78.8 \%$ at late phase respectively while acetyl salicylic acid $(100 \mathrm{mg} / \mathrm{kg}$ ), responsible for $25.58 \%$ and $38.74 \%$ of inhibition at both phase sequentially. Again, the crude extract significantly $(p<0.01 ; p<0.001)$ raised the time spent in the open arm $\left(149.2 \pm 27.63^{* *} \mathrm{sec}\right)$ \& the number of head-dips $\left(50.00 \pm 4.66^{* * *}\right)$ at the dose $400 \mathrm{mg} / \mathrm{kg}$ body weight in case anxiolytic test, while reference drug diazepam $\left(1 \mathrm{mg} / \mathrm{kg}\right.$ body weight) also exhibited significant $(p<0.01)$ result in case of time spent in open arm $\left(107.0 \pm 12^{* *} \mathrm{sec}\right)$ but not for head dipping (14.83 \pm 1.6$)$.

Conclusion: Findings of the present study assure that Typha elephantina Roxb. may be effective for the treatment of pain and anxiety with the demands of further investigations to isolate the active compound(s).

Keywords: Typha elephantina Roxb., Analgesic, Anxiolytic, Swiss-albino mice

\section{Background}

Pain is a kind of convoluted unsavoury phenomenon which consists of sensory experiences including time, space, intensity, emotion, cognition and motivation. The agents which are being used to attenuate pain either by acting in the central nervous system (CNS) or by peripheral pain mechanisms except altering the consciousness are called analgesic [1]. Recently attainable analgesic drugs such

\footnotetext{
* Correspondence: niloysen91@gmail.com

'Department of Pharmacy, Noakhali Science \& Technology University,

Noakhali-3814, Bangladesh

Full list of author information is available at the end of the article
}

as non-steroidal anti-inflammatory drugs (NSAIDs) alleviate pain and edema by repressing the synthesis of prostaglandin or by blocking the action of cyclooxygenase enzymes in inflammatory pathways. On the other hand, opiates act by affecting the central nervous system [2]. But severe side effects such as gastric lesion caused by NSAIDs and tolerance, dependence introduced by opiates have been making them unsuccessful in many cases [3]. In this sense, it is exigent to investigate novel analgesic drugs as a substitute of NSAIDs and opiates with prosperous pain management capability and free from undesirable adverse effects [4]. 
Modern life stress linked with various tests and afflictions plays the pivotal role for the surge of a variety of psychiatric disorders [5]. Among many psychiatric disorders anxiety disorders, are the most dominant problems and about $10-30 \%$ of general population is suffering from these throughout the world [6]. Benzodiazepines are the most frequently prescribed synthetic drugs for their anxiolytic, muscle relaxant, sedative-hypnotic and anticonvulsant actions [7]. Not only impairment in cognitive functions, physical dependence and tolerance side effects, these psychoneural drugs also cause harmful effects on respiratory, digestive and immune systems of the body [5]. That's why the search for new anxiolytic agents with reduced adverse effects is still an area great interest for the researchers [6].

Generally, natural products, specifically medicinal plants are considered to be a vital arsenal of chemical substances with therapeutic potentiality [4]. In the account of this, our concentration has been focused particularly on Typha elphantina Roxb. belonging to the family Typhaceae, a bush like small plant which was locally known as Hogla. The plant grows plenty in the Sundarban forest as well as in other low lying areas of Sylhet, Chittagong in beels \& haors [8]. Typha elephantina Roxb. widely scattered across northern Africa and southern Asia. It is defined as native in many countries all over the world such as Algeria, Egypt, Libya, Uzbekistan, Palestine, Israel, Saudi Arabia, Assam, Bangladesh, India, Bhutan, Nepal, Pakistan and Burma etc. [9]. It is cooling and aphrodisiac in nature; used in splenic enlargement, burning sensation and leprosy. The root-stock has astringent and diuretic properties, also useful in case of dysentery, gonorrhoea and measles and the ripe fruits and the soft and woolly floss of male spikes are used as medicated absorbent to wounds and ulcers in emergency cases [10]. Several chromatographic and spectroscopic analysis carried out on fruit extract of this plant revealed the presence of four chemical constituents named pentacosane, 1triacontarol, $\beta$-sitosterol, $\beta$-sitostery-3-O- $\beta$ glycopyranoside. These four chemical constituents are supposed to exert various pharmacological activities such as antiinflammatory, anti-pyretic, anti-tumour activities etc. [11]. As a part of our perpetual investigations on medicinal plants of Bangladesh, the methanolic extract of Typha elephantia Roxb. was studied for finding its analgesic activity and anxiolytic potentiality.

\section{Methods}

\section{Drugs and chemicals}

Acetic acid and formalin were obtained from Sigma Chemicals, USA; while Aspirin and Sedil were purchased from Square Pharmaceuticals Ltd., Bangladesh. Both of them are internationally recognized as acetyl salicylic acid and diazepam respectively as their chemical name.
Other reagents of the analytical grade for conducting this research work were supplied from the ethnopharmacology laboratory of Pharmacy department of Noakhali Science and Technology University.

\section{Plant materials}

The whole plant was collected from Noakhali Science and Technology University campus, Sonapur, Noakhali, Chittagong during January 2015. The plant was ascertained by an expert of Bangladesh National Herbarium, Mirpur, Dhaka, Bangladesh (Accession number- DACB: 43,476). The plant parts were sundried in shadow type milieu for 10 days and then subjected to be grounded by the use of high capacity grinding machine to produce coarse powder using.

\section{Preparation of plant extracts}

$800 \mathrm{~g}$ powder of the whole plant was soaked in $4.5 \mathrm{l}$ methanol in a desiccator through occasional shaking and stirring. After 15 days the solvent was removed and filtration was carried out by using sterile cotton \& Whatman filter paper no. 1 (Sargent, Welch, USA). Then rotary evaporation was carried out to concentrate the filtrate and was kept at room temperature in fresh and clean air for obtaining a brownish mass.

\section{Pharmacological procedure \\ Animals}

Healthy Swiss albino mice (25-30 g) either sex were employed for this study. These mice were collected from Pharmacy Department, Jahangir Nagar University, Savar, Dhaka, Bangladesh and were kept in polypropylene plastic cages having dimensions of $30 \times 20 \times 13 \mathrm{~cm}$ and softwood shavings were employed as bedding in the cages. Feeding of the animal was done along with standard laboratory pellet diet and water at libitum, exposing them to an alternate cycle of $12 \mathrm{~h}$ dark and light, at temperature $25 \pm 2{ }^{\circ} \mathrm{C}$ and relative humidity $55 \pm$ $10 \%$. All the mice were allowed to acclimatize for 7 days to the laboratory conditions before conducting the experiment.

\section{Preparation of test samples for bioassay}

In order to administer $200 \mathrm{mg} / \mathrm{kg}$ and $400 \mathrm{mg} / \mathrm{kg}$ concentrations of the sample, extract amount was calculated based on the weight of the mice and properly mixed with $10 \mathrm{ml}$ distilled water using vortex mixer. Acetyl salicylic acid (ASA) at a dose $100 \mathrm{mg} / \mathrm{kg}$ was properly calculated and mixed with $10 \mathrm{ml}$ distilled water with the assistance of tween- 80 by subsequent used of vortex mixer and sinker for proper mixing and used as reference standard for the analgesic test. Diazepam at a dose $1 \mathrm{mg} / \mathrm{kg}$ was properly calculated and mixed properly 
with $10 \mathrm{ml}$ distilled water. This one was used as reference standard for the anxiolytic test.

\section{Acute toxicity test}

Animals were intraperitoneally (i.p.) employed to a high dose $(2 \mathrm{~g} / \mathrm{kg})$ of Typha elephantina extract. Than observed during $24 \mathrm{~h}$ and morbidity or mortality was recorded, it happens, for each group at the end of observation period. Hayes stated that no dose-related toxicity should be considered above $5 \mathrm{~g} / \mathrm{kg}$ body weight, thus suggesting that the extract is relatively non-toxic administered [12].

\section{Analgesic activity}

\section{Acetic acid induced writhing test}

The analgesic activity of the extract was conducted by using acetic acid-induced writhing in mice model. Twenty mice (25-30 g) were taken for this test and they were divided into four groups named as negative control group (Group I), positive control group (Group II), and two test groups (Group III \& IV) with five mice in each group. They have fasted for $18 \mathrm{~h}$. Group I mice were given distilled water $10 \mathrm{ml} / \mathrm{kg}$, i.p.; group II mice was given $100 \mathrm{mg} / \mathrm{kg}$ acetyl salicylic acid subcutaneously (s.c.) while group III and IV i.p. received 200 and $400 \mathrm{mg} / \mathrm{kg}$ per body weight of crude methanolic extract respectively. After one hour of administration of drug and extract, $0.6 \%$ glacial acetic acid $(10 \mathrm{ml} / \mathrm{kg})$ was given i.p. to all the mice to induce pain [13]. The number of writhes (characterized by contraction of the abdominal musculature and extension of the hind limbs) was then counted at $5 \mathrm{~min}$ interval for $30 \mathrm{~min}$. The percentage of protection against abdominal writhing was used to assess the degree of analgesia and was calculated by using the formula given below [14].

For Acetic acid-induced writhing test:

Inhibition $(\%)=\frac{\text { Number of writhes }(\text { control })-\text { number of writhes }(\text { test })}{\text { Number of writhes }(\text { control })} \times 100$

\section{Formalin induced hind paw licking test}

Formalin-induced hind paw licking test also conducted to ascertain the analgesic property of the crude methanolic extract in mice model. Like acetic acid-induced writhing test here also twenty swiss albino mice (25$30 \mathrm{~g}$ ) were selected and divided into four groups (Group I, II, III \& IV) of five mice per group. After passing through a fasting condition of $18 \mathrm{~h}$ by all animals group I (negative control group) mice were given distilled water $10 \mathrm{ml} / \mathrm{kg}$ per body weight i.p. Acetyl salicylic acid $100 \mathrm{mg} / \mathrm{kg}$ per body weight were given s.c. to group II (positive control group) mice as standard drug. On the other hand, 200 and $400 \mathrm{mg} / \mathrm{kg}$ per body weight doses of crude methanolic extract were administered i.p. to group III and IV as test samples. After one hour a s.c. injection was given beneath the plantar surface of the left hind paw of each mice to introduce $20 \mu \mathrm{L}$ of $2.5 \%$ formalin. [15] The time (in a second) spent in licking and biting responses of the injected paw was taken as an indicator of pain response. In this test, the determination of Anti-nociceptive effect involved two phases. The early phase (phase 1) was recorded during the first $5 \mathrm{~min}$, while the late phase (phase 2) was counted during the last 20-30 min after formalin injection [16, 17].

For formalin-induced hind paw licking test:

$$
\text { Inhibition }(\%)=\frac{\text { Reaction time }(\text { control })-\text { Reaction time }(\text { test })}{\text { Reaction time }(\text { control })} \times 100
$$

\section{Anxiolytic activity \\ Elevated plus maze test}

The crude methanolic extract was assessed to determine the anxiolytic activity by the way of using an Elevated Plus Maze model (EPM). According to the description given by Lister, the EPM was constructed (1987). The EPM consisted of two open arms $(35 \times 5 \mathrm{~cm})$ crossed with two closed arms $(35 \times 5 \times 15 \mathrm{~cm})$. The arms were connected together with a central square of $5 \times 5 \mathrm{~cm}$. The apparatus was elevated to the height of $40 \mathrm{~cm}$ in a dimly illuminated room. Twenty Swiss albino mice (25$30 \mathrm{~g}$ ) fasted overnight were randomly selected and categorized into four groups of five animals each denoted as negative control group (Group I), positive control group (Group II) and test groups (Group III \& IV). Distilled water $10 \mathrm{ml} / \mathrm{kg}$, diazepam $1 \mathrm{mg} / \mathrm{kg}$, plant extracts $200 \mathrm{mg} / \mathrm{kg}$ and $400 \mathrm{mg} / \mathrm{kg}$ were administered to group I, II, III \& IV mice respectively. Experimental animals of all groups were treated by i.p. route. After $1 \mathrm{~h}$, mice were individually placed in the center square facing either one of the open arms. The time spent by each mouse in both the open and closed arms was counted for 5 min [18].

\section{Hole board test}

In the present study, the anxiolytic property also evaluated by the aid of another model recognized as Hoal

Table 1 Effects of Typha elephantina extract on acetic acid induced writhing in mice

\begin{tabular}{lllll}
\hline Groups & Drugs & Dose & $\begin{array}{l}\text { Number of } \\
\text { Writhes (15 min) } \\
\text { Mean } \pm \text { S.E.M }\end{array}$ & \% of inhibition \\
\hline I & Control & $10 \mathrm{ml} / \mathrm{kg}$ & $20.4 \pm 4.2$ \\
II & ASA & $100 \mathrm{mg} / \mathrm{kg}$ & $15 \pm 4.5^{*}$ & $26.47 \%$ \\
III & Extract & $200 \mathrm{mg} / \mathrm{kg}$ & $10.2 \pm 0.58^{* * *}$ & $50.49 \%$ \\
IV & Extract & $400 \mathrm{mg} / \mathrm{kg}$ & $6.2 \pm 0.37^{* * *}$ & $70.29 \%$ \\
\hline
\end{tabular}

Here, ASA Acetyl Salicylic Acid, S.E.M Standard Error Mean. Results are presented as mean values \pm S.E.M. $(n=5)$

${ }^{*} p<0.05,{ }^{* * *} p<0.001$ when compared to control group 
Table 2 Effects of Typha elephantina extract on formalin induced hind paw licking mice (Early phase: 0-5 min and late phase: 20-30 min)

\begin{tabular}{|c|c|c|c|c|c|c|}
\hline Groups & Drugs & Dose & $\begin{array}{l}\text { Time of Hind Paw } \\
\text { licking (0-5 min) } \\
\text { Mean } \pm \text { S.E.M. }\end{array}$ & $\begin{array}{l}\% \text { of inhibition } \\
\text { (Early phase) }\end{array}$ & $\begin{array}{l}\text { Time of Hind } \\
\text { Paw licking } \\
\text { Mean } \pm \text { S.E.M }\end{array}$ & $\begin{array}{l}\text { \%of inhibitior } \\
\text { (20-30 min) }\end{array}$ \\
\hline I & Control & $10 \mathrm{ml} / \mathrm{kg}$ & $43 \pm 5.1$ & & $74.6 \pm 14.6$ & \\
\hline$\|$ & ASA & $100 \mathrm{mg} / \mathrm{kg}$ & $32 \pm 7.1$ & $25.58 \%$ & $45.7 \pm 7.8^{*}$ & $38.74 \%$ \\
\hline III & Extract & $200 \mathrm{mg} / \mathrm{kg}$ & $19.8 \pm 2.22^{* *}$ & $53.95 \%$ & $28.5 \pm 1.58^{* * *}$ & $61.79 \%$ \\
\hline IV & Extract & $400 \mathrm{mg} / \mathrm{kg}$ & $12.2 \pm 0.80^{* * *}$ & $71.62 \%$ & $15.8 \pm 0.55^{* * *}$ & $78.8 \%$ \\
\hline
\end{tabular}

Here, ASA Acetyl Salicylic Acid, S.E.M Standard Error Mean. Results are presented as mean values \pm S.E.M. $(n=5)$

${ }^{*} p<0.05,{ }^{* *} p<0.01,{ }^{* *} p<0.001$ when compared to control group

Board model. The hole-board consists of a wooden box $(40 \times 40 \times 25 \mathrm{~cm})$ with 16 holes (each of diameter $3 \mathrm{~cm}$ ) evenly distributed on the floor. The apparatus was $35 \mathrm{~cm}$ in height. Similarly, twenty Swiss albino mice (25-30 g) were kept on fast for an overnight and again separated into four groups of five animals denoted as group I (negative control group), group II (positive control group) and group II \& IV (test sample groups). These four groups of animals were treated by i.p. route with distilled water $(10 \mathrm{ml} / \mathrm{kg})$, diazepam $(1 \mathrm{mg} / \mathrm{kg})$, and plant extract (200 and $400 \mathrm{mg} / \mathrm{kg}$ ) respectively. After one hour each mouse was placed in turn at one corner of the board and then renders the animal to move and dip its head into the holes. The number of head dips during a $5 \mathrm{~min}$ period was recorded for individual mouse [19-21].

\section{Statistical analysis}

All the results were expressed as mean \pm SEM. $P$-value was calculated by one-way ANOVA using SPSS software, version 22.0 (IBM Corporation, New York, NY, U.S.A.). Where, ${ }^{*} p<0.05,{ }^{* * *} p<0.01,{ }^{* * * *} p<0.001$ stands for significant, more significant and most significant respectively.

\section{Results}

The present study was an attempt to determine the analgesic and anxiolytic properties of methanolic extract of Typha elephantina Roxb. and the results have been circumscribed in Tables 1, 2, 3, and 4 respectively.

Table 3 Effects of methanolic extract of Typha elephantina on mice in the open arm and closed arm of the EPM

\begin{tabular}{lllll}
\hline Groups & Drugs & Doses & $\begin{array}{l}\text { Time spent in } \\
\text { open arm (sec) } \\
\text { Mean } \pm \text { S.E.M. }\end{array}$ & $\begin{array}{l}\text { Time spend in } \\
\text { closed arm (sec) } \\
\text { Mean } \pm \text { S.E.M. }\end{array}$ \\
\hline I & Control & $10 \mathrm{ml} / \mathrm{kg}$ & $30.8 \pm 6.4$ & $243.5 \pm 8.8$ \\
III & Diazepam & $1 \mathrm{mg} / \mathrm{kg}$ & $107.0 \pm 12^{* *}$ & $169 \pm 13.1^{* *}$ \\
IV & Extract & $200 \mathrm{mg} / \mathrm{kg}$ & $82.6 \pm 13.24$ & $217.6 \pm 13.24$ \\
\hline
\end{tabular}

Results are presented as mean values \pm S.E.M. $(n=5)$

${ }^{*} p<0.05,{ }^{* *} p<0.01$ when compared to control group

\section{Acute toxicity test}

In respect of acute toxicity, the extract did not produce any mortality and visible signs of delayed toxicity administered i.p. up to $2 \mathrm{~g} / \mathrm{kg}$.

\section{Analgesic activity}

As a part of searching drugs from natural sources having the potentiality to remove pain, the extractives of Typha elephantina was examined for analgesia effect and the results are presented in Tables 1 and 2 respectively for acetic acid induced writhing test and formalin induced hind paw licking test. From Table 1 it has been noticed that there was ebb in the average number of writhes in the both extract groups (Group III \& IV) in a dose-dependent manner and ASA group (Group II), in comparison with the negative control group (Group I). The crude methanolic extract at the afore-mentioned two doses $(200 \mathrm{mg} / \mathrm{kg} \& 400 \mathrm{mg} / \mathrm{kg}$ body weight) was significantly susceptible in the inhibition of pain respectively by $50.49 \% \& 70.29 \%$. These results were statistically most significant $(p<0.01, p<0.001)$ when compared to control. Standard anti-nociceptive drug, ASA, when administered at the dose of $100 \mathrm{mg}$ per $\mathrm{kg}$ body weight, exhibited $26.47 \%$ of pain inhibition, which was also found statistically significant $(p<0.05)$ in contrast with control. Here Table 1 and Fig. 1 altogether displayed the results of acetic acid induced writhing test for anti-nociceptive activity. On the other hand, the results of formalin induced hind paw licking test were summarized in Table 2 including both the early phase and late phase. Table 2 demonstrates that both the extract doses $(200 \mathrm{mg} / \mathrm{kg} \& 400 \mathrm{mg} / \mathrm{kg})$ were responsible for attenuating hind paw licking time

Table 4 Effects of methanolic extract of Typha elephantina on mice stay in the hole board

\begin{tabular}{llll}
\hline Groups & Drugs & Doses & $\begin{array}{l}\text { Number of Head Dipping } \\
\text { Mean } \pm \text { SEM }\end{array}$ \\
\hline I & Control & $10 \mathrm{ml} / \mathrm{kg}$ & $10.50 \pm 1.3$ \\
$\|$ & Diazepam & $1 \mathrm{mg} / \mathrm{kg}$ & $14.83 \pm 1.6$ \\
III & Extract & $200 \mathrm{mg} / \mathrm{kg}$ & $44.8 \pm 2.05^{* * *}$ \\
IV & Extract & $400 \mathrm{mg} / \mathrm{kg}$ & $50.00 \pm 4.66^{* * *}$ \\
\hline Results are presented as mean values \pm S.E.M. $(n=5)$ \\
*** $^{* * 0}<0.001$ when compared to control group
\end{tabular}




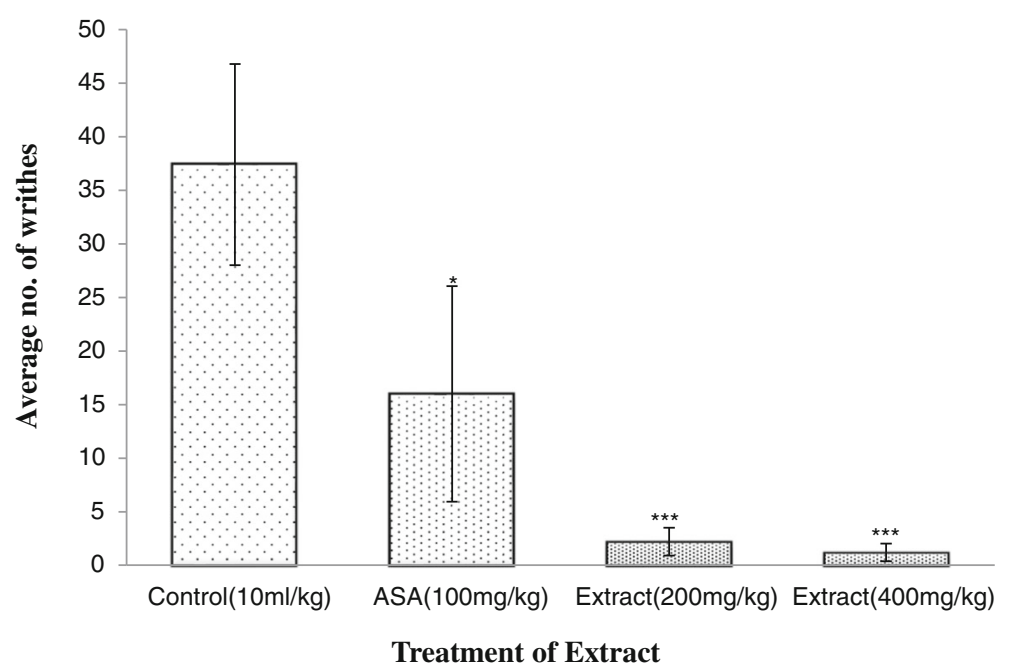

Fig. 1 Effects of Typha elephantina extract on acetic acid induced writhing in mice. Results are presented as mean values \pm S.E.M. $(n=5)$; ${ }^{*} p<$ $0.05,{ }^{* *} p<0.001$ when compared to control group

significantly $(p<0.01, \mathrm{p}<0.001)$ where the percentages of inhibition of hind paw licking were 53.95\% \& 71.62\% during early phase and $61.79 \%$ \& $78.8 \%$ during late phase respectively. The reference drug acetyl salicylic acid which was administered as positive control also exerted preferable time reducing effect for hind paw licking by $25.58 \%$ and $38.74 \%$ respectively for both phases. The results of acetic acid hind paw licking test also displayed graphically in Figs. 2 and 3.

\section{Anxiolytic activity}

The crude methanolic extract of Typha elephantina Roxb. was also assayed for anxiolytic activity by using
EPM and hole board and the results are annexed in Tables 3 and 4 respectively. From Table 3 it can be inferred that, control group mice spent much time in the closed arm and refrain them from entering into the open arm. The average of time spent (sec) by the group IV mice treated with extract dose $400 \mathrm{mg} / \mathrm{kg}$ body weight was more significantly $(p<0.01)$ increased in open arm and decreased in closed arm by $149.2 \pm 27.63^{* * * *} \mathrm{sec}$ and $150.8 \pm 27.63^{* * *} \mathrm{sec}$ respectively when compared to control. The other extract dose (200 mg per $\mathrm{kg}$ body weight) also exhibited similar attribute of effect but have no statistical significance in contrast with control. The reference drug diazepam relieved anxiety better than extract dose $200 \mathrm{mg} / \mathrm{kg}$ which was also statistically more significant

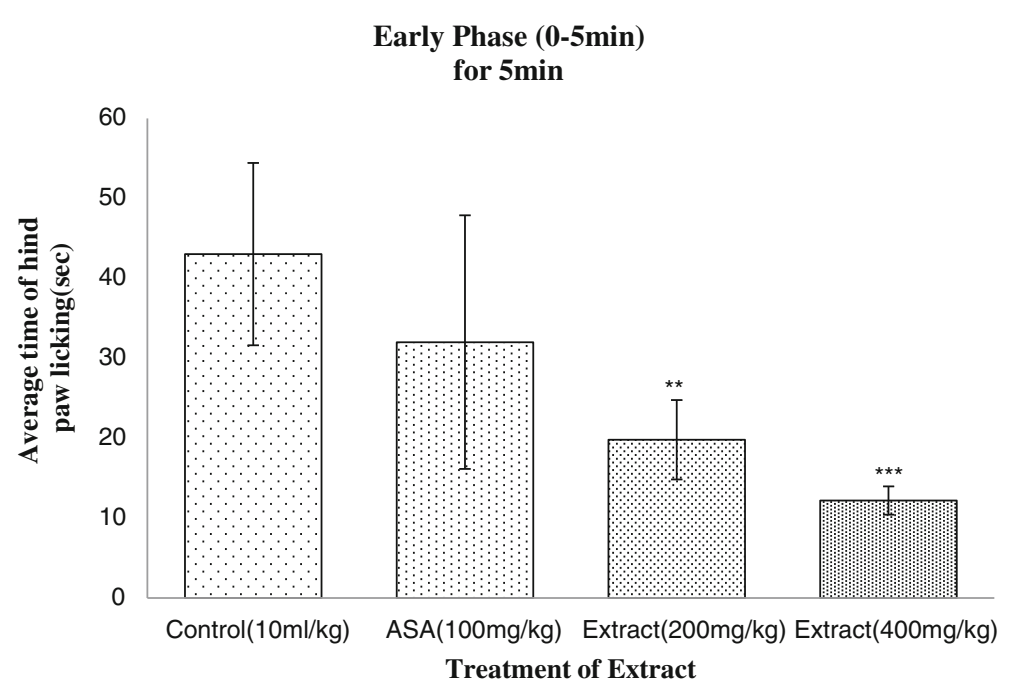

Fig. 2 Effects of Typha elephantina extract on formalin induced hind paw licking mice (Early phase: $0-5$ min). Results are presented as mean values \pm S.E.M. $(n=5) ;{ }^{*} p<0.05,{ }^{* *} p<0.001$ when compared to control group 


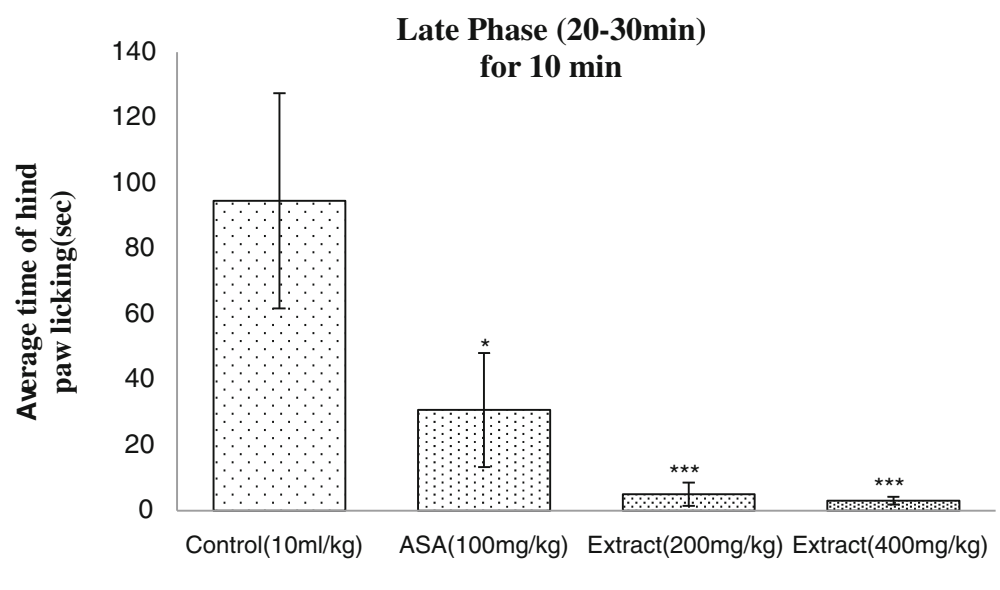

Treatment of Extract

Fig. 3 Effects of Typha elephantina extract on formalin induced hind paw licking mice (Late phase: 20-30 min). Results are presented as mean values \pm S.E.M. $(n=5) ;{ }^{* *} p<0.01,{ }^{* * *} p<0.001$ when compared to control group

$(p<0.01)$ as compared to control group but less effective than $400 \mathrm{mg} / \mathrm{kg}$ body weight extract dose. The average of time spent by these positive control group mice were $107.0 \pm 12^{\text {w*m }} \mathrm{sec}$ in open arm and $169 \pm$ $13.1^{* * *} \mathrm{sec}$ in closed arm respectively. Figure 4 is used to represent these results graphically. The results of hole board test are manifested in Table 4 and Fig. 5 to represent the anxiolytic effect of a crude methanolic extract of Typha elephantina Roxb. Both the extract doses $(200 \mathrm{mg} / \mathrm{kg}, 400 \mathrm{mg} / \mathrm{kg})$ most significantly $(p<0.001)$ ameliorated the numbers of head dipping in a dose-dependent manner when compared to control. On average $44.8 \pm 2.05^{m * n}$ and $50.00 \pm 4.66^{m * n}$ head dips were performed by group III \& IV mice respectively. However, no significant increases were observed in the number of head dipping in case mice treated with diazepam $(1 \mathrm{mg} / \mathrm{kg})$.

\section{Discussion}

The present study was carried out in order to assess the analgesic and anxiolytic effects crude methanolic extract of Typha elephantina Roxb. on animals while the acute toxicity study provides evidence about the non-toxicity of this plant. From obtained results, it might be asserted that the plant extract possesses significant inhibition of pain and abatement of anxiety with a considerable safety profile.

Acetic acid-induced twisting of dorsoabdominal muscles constrictions [22], followed by the measurement of a number of writhing is one of the most important methods for the determination of both central and peripheral analgesia [4], as had been done in the present study. In this test, pain sensation is elicited by instigating localized inflammatory response which associated with the release of free arachidonic acid from tissue

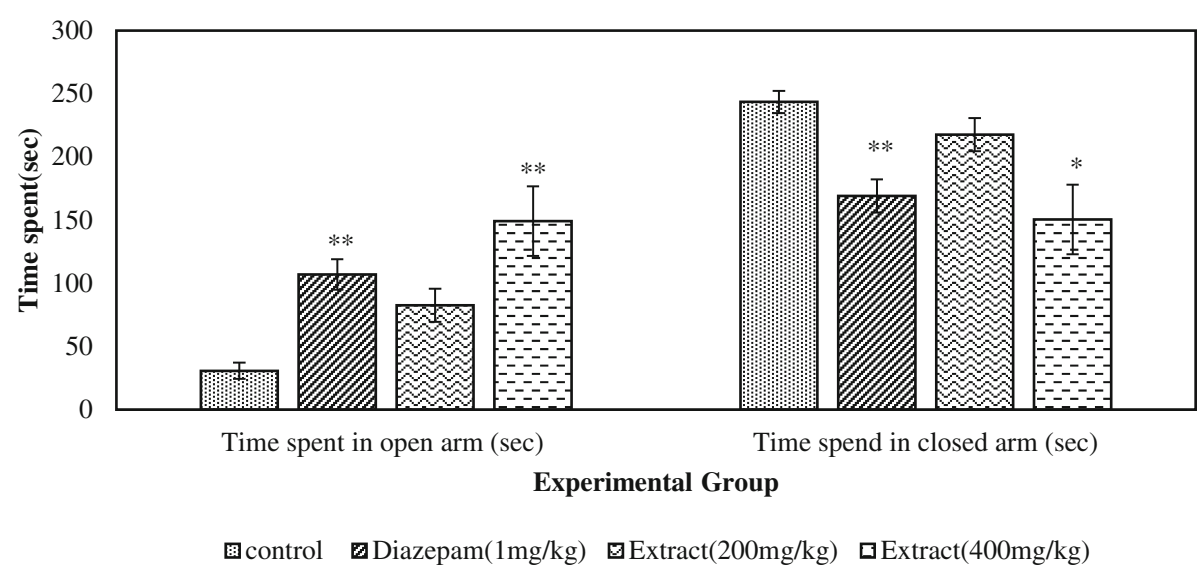

Fig. 4 Effects of methanolic extract of Typha elephantina on mice in the open arm and closed arm of the EPM. Results are presented as mean values \pm S.E.M. $(n=5) ;{ }^{*} p<0.05,{ }^{*} p<0.01$ when compared to control group 


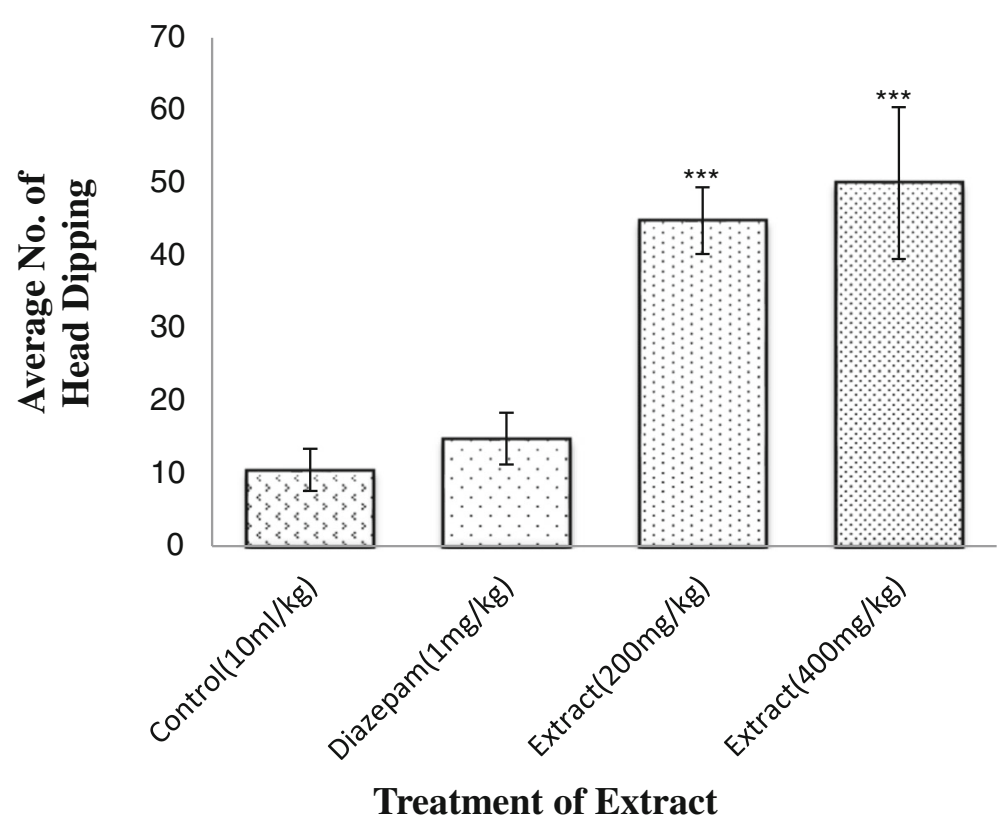

Fig. 5 Effects of methanolic extract of Typha elephantina on mice stay in the hole board. Results are presented as mean values \pm S.E.M. $(n=5) ;{ }^{* * *} p<$ 0.001 when compared to control group

phospholipid via cyclooxygenase (COX), and prostaglandin biosynthesis [23, 24]. In other words, the levels of PGE2 and PGF2 $\alpha$, as well as lipoxygenase products are supposed to be increased in the peritoneal cavity due to acetic acid administration [25]. These excess amounts of prostaglandins within the peritoneal cavity then accelerates inflammatory pain by facilitating capillary permeability [26]. It is widely acceptable that NSAIDs serve as an inhibitor of inflammatory pain at peripheral target sites through the formation of the blockade against pin mediators such as bradykinin and prostaglandins which play important role in the generation of pain [27]. From our investigation, it was observed that methanolic extract of Typha elephantina at two different doses (200 mg/kg and $400 \mathrm{mg} / \mathrm{kg}$ body weight) demonstrated a significant reduction of writhes in mice in a dosedependent manner as compared to control (distilled water). So it can be assumed that its cyclooxygenase (COX) inhibitory activity may reduce the production of free arachidonic acid from phospholipid or may inhibit the enzyme system, which is responsible for the synthesis of prostaglandins and ultimately relieve pain sensation.

As acetic acid-induced writhing test is sensitive but not selective, thus formalin-induced hind paw licking test also conducted in order to endorse the analgesic activity of the plant extract. On the other hand, previous studies have shown that formalin plays a vital role in secreting several inflammatory mediators. The formalininduced hind paw licking test describes two types of response, i.e. 'early response' or first phase (neurogenic pain) and 'late response' or second phase (inflammatory pain) $[14,28]$.

Moreover, formalin-induced nociception is also associated with direct action on a member of Transient Receptor Potential family (TRP) of cation channels denoted as TRPA1 receptor located in C fibres [29]. It is also observed from our study that both the extract doses (200 $\mathrm{mg} / \mathrm{kg}$ and $400 \mathrm{~kg} / \mathrm{kg}$ body weight) significantly mitigate not only neurogenic pain but also the inflammatory pain in a dose-dependent manner. So it can be assumed that Typha elephantina extract acts against formalin-induced nociception by interacting with the TRPA1receptor. However, previous studies on several plant extracts revealed that potential antioxidants, alkaloids, glycosides, flavonoids and saponins are reported to play role in analgesic activity primarily by targeting prostaglandin [30-33]. Since phytochemical analysis ensured the presence of flavonoids, tannin, phenols, saponin alkaloid in the crude extract of Typha elephantina Roxb [9] and the obtained results suggest that, methanolic extract of Typha elephantina possesses a significant analgesic effect in this paradigm.

The prominent inhibitory neurotransmitter in the human central nervous system is Gamma-aminobutyric acid (GABA). It has been reported that the GABAergic system substantiates a promising destination for new pharmacological techniques for the treatment of anxiety [34]. As the increment in GABAergic neurotransmission was connected with reduced anxiety; over the years, 
different pharmacological models have been appointed in the evaluation of medicinal plants for neuropharmacological activities towards the identification of botanicals and drugs with beneficial effects in the treatment of diverse CNS disorders. The choice of test methods not only determines effectiveness but in some instances also gives an indication of the mechanism(s) of the test substance $[35,36]$. Models that are available for evaluating anxiolytic or anxiogenic traits of substances, hole board and EPM in rodents are most promising among them [37, 38]. On account of this, the present study was designed to investigate the anxiolytic properties of methanolic extract in EPM and hole board by using Swiss-albino mice. Moreover, it is known that anxiolytic agents raise the time spent in open arms of the EPM [37]. According to our study, administration of two different doses of plant extract $(200 \mathrm{mg} / \mathrm{kg}$ \& $400 \mathrm{mg} / \mathrm{kg}$ body weight, i.p.) significantly increased $(p<$ 0.05 ) the permanence time in open arms, in comparison to control group. The plant extract at an increased dose (400 mg/ $/ \mathrm{kg}$ body weight) likely to be more effective than diazepam $(1 \mathrm{mg} / \mathrm{kg})$ group in comparison to another experimental group ( $200 \mathrm{mg} / \mathrm{kg}$ body weight). Hole board test is founded on a supposition that head-dipping of animals is inversely proportional to their anxiety state in the moderately aversive environment [39]. Therefore the increased number of head dips into the holes on the board means waned anxiety state. Drugs as diazepam not significantly increase the number of head-dips in the hole-board test as compared to control. Our study revealed that, methanolic extract of Typha elephantina (200 and $400 \mathrm{mg} / \mathrm{kg}$, i.p.) increased head-dip counts without changing locomotion in the hole-board test most significantly $(p<0.001)$ as compared with control group. Flavonoids, alkaloids, and terpenoids have been reported to be responsible for anxiolytic and sedative effects observed in different plant extracts [40-42]. On the other hand, the presence of natural flavonoids that hold anxiolytic effect not linked with myorelaxant, amnestic or sedative effects has been manifested [7]. As we stated above about the existence of flavonoids in methanolic extract of Typha elephantina it can be hypothesized flavonoids is responsible for its antianxiety action.

\section{Conclusion}

Based on the above denouements it can be asserted that the methanolic extract of Typha elephantina Roxb. is a promising source of necessary phytochemicals having potentiality to assuage pain and anxiety. Therewith this plant could be better remedy for pain and anxiety disorders in traditional manner. Therefore it may suggest further investigations in order to disclose the underlying causes of analgesic and anxiolytic actions scientifically.

\section{Abbreviations}

ASA: Acetyl Salicylic Acid; CNS: Central Nervous System; COX: Cyclooxygenase; EPM: Elevated Plus Maze Model; GABA: Gamma-aminobutyric acid; NSAIDS: Non-steroidal Anti-inflammatory Drugs; SC: Subcutaneously; TRP: Transient Receptor Potential family (TRP)

\section{Acknowledgements}

The authors are grateful to Square Pharmaceuticals Ltd., Bangladesh for their generous supply of necessary drugs. The authors are also thankful to all the teachers and staffs of the Department of Pharmacy, Noakhali Science and

Technology University for their cordial co-operation by providing laboratory support to carry out the research work.

\section{Funding}

The research work was partially supported by the Department of Pharmacy, Noakhali Science and Technology University, Bangladesh. The authors have no other relevant affiliations or financial involvement with any organization.

\section{Availability of data and materials}

All data and materials are contained and described within the manuscript. The data set was deposited in publicly available repositories. The plant's materials for the study were identified and voucher specimens are deposited at Pharmacy Department of Noakhali Science and Technology University.

\section{Authors' contributions}

LB designed the experiments and conception. NS conducted the research work. Data interpretation and analysis were aided by MSH. SB critically reviews the manuscript. MSKC made the necessary corrections in the write up and gave final approval for the submission of revised version. All authors read and approved the final manuscript.

\section{Authors' information}

Niloy Sen is a Post Graduate student of Department of Pharmacy, Noakhali Since \& Technology University, Noakhali-3814, Bangladesh; Latifa Bulbul and Sujan Banik are working as Assistant Professor at Department of Pharmacy, Noakhali Science and Technology University, Noakhali-3814, Bangladesh. Md. Saddam Hussain is also a Post Graduate student of Department of Pharmacy, Noakhali Science and Technology University, Noakhali-3814, Bangladesh. Finally, Md. Shahbuddin Kabir Choudhuri is the Professor of Pharmacy Department, Jahangirnagar University, Dhaka-1342, Bangladesh.

\section{Ethics approval and consent to participate}

All authors hereby declare that "Principles of laboratory animal care" (NIH publication No. 85-23, revised 1985) were followed, as well as specific national laws where applicable. All experiments have been examined and approved by the appropriate ethics committee.

\section{Consent for publication}

All authors have given their valuable consent to publish this article.

\section{Competing interests}

The authors declare that they have no competing interests.

\section{Author details}

${ }^{1}$ Department of Pharmacy, Noakhali Science \& Technology University, Noakhali-3814, Bangladesh. ²Department of Pharmacy, Jahangirnagar University, Dhaka-1342, Bangladesh.

Received: 28 July 2017 Accepted: 8 January 2018

Published online: 07 February 2018

\section{References}

1. Milind P, Monu Y. Laboratory Method For Sreening analgesics. Int Res J Pharm. 2013:4:15

2. Mishra D, Ghosh G, Kumar PS, Panda PK. An Experimental study of analgesic activity of selective cox-2 inhibitor with conventional NSAIDs. Asian J Pharm Clin Res. 2011:4:78-81.

3. AHM Z, Rahman MM, Kamal M, Hossain MK, Hamid K, MEH M, Rana MS. In vivo analgesic activity of ethanolic extracts of two medicinal plants - Scoparia dulcis L. and Ficus Racemosa Linn. Biol Med. 2010;2:42-8. 
4. Shanmugasundaram P, Venkataraman S. Anti-nociceptive activity of Hygrophila auriculata (SCHUM) Heine. Afr J Trad CAM. 2005;2:62-9.

5. Mishra SK, Sing PN, Dubey SD. Evaluation of CNS depressant activity of Capparis zeylenica Linn. Root. Res J Med Plants. 2011;5:738-46.

6. Netto SM, Warela RWB, Fechine MF, Queiroga MN, Quintans-Júnior LJ. Anxiolytic-like effect of Rauvolfia Ligustrina Willd. Ex Roem. \& Schult. Apocynaceae, in the elevated plus-maze and hole-board tests. BJP. 2009;19:888-92.

7. Helli'on-Ibarrola MC, DAY I, Montalbetti Y, Kennedy ML, Heinichen O, Campuzano M, Tortoriello J, Tortoriello J, Fern'andez S, Wasowski C, Marder M, TCM DL, Morae S. The anxiolytic-like effects of Aloysia polystachya (Griseb.) Moldenke (Verbenaceae) in mice. J Ethnopharmacol. 2006;105:400-8.

8. Sen N, Bulbul L, Hussain F, Amin MT. Assessment of thrombolytic, membrane stabilizing potential and total phenolic content of Typha elephantina Roxb. J Med Plants Res. 2016:10:669-75.

9. Rahman MM, Chakrabarty JK, Muhit MA, Dash PR. Evaluation of analgesic activity of the different fractions of Typha elephantina Roxb. IJP. 2014;1:380-3.

10. Bulbul L, Kader MA, Baul S, Uddin SMN, Haque MM, Debnath PC, Kar A. In vitro anthelmintic and cytotoxic activities of the methanolic extract of Typha elephantina Roxb. IAJPR. 2013;3:3519-26.

11. Ruangrungsi N, Aukkanibutra A, Phadungcharoen T, Lee M. Constituents Of Typhaelephantina. J Sci Soc. 1987;13:57-62.

12. Hayes AW. Guidelines for acute oral toxicity testings: Principles and Methods of Toxicity, second ed. Raven Press Ltd., New York. Table. 1989; 4: 185.

13. Ezeja MI, Omeh YS, Ezeigbo II, Ekechukwu A. Evaluation of the analgesic activity of the Methanolic stem bark extract of Dialium Guineense (wild). Ann Med Health Sci Res. 2011;1:55-62.

14. Akindele AJ, Ibe IF, Adeyemi OO. Analgesic and antipyretic activities of Drymaria Cordata (Linn.) Willd (Caryophyllaceae) extract. Afr J Tradit Complement Altern Med. 2012;9:25-35.

15. Hunskaar $\mathrm{S}$, Hole $K$. The formalin test in mice: dissociation between inflammatory and non-inflammatory pain. Pain. 1987;30:103-14.

16. Shibata M, Ohkubo T, Takahashi H, Inoki R. Modified Formalin test: characteristic biphasic pain response. Pain. 1989;38:347-52.

17. Ullah HMA, Zaman S, Juhara F, Akter L, Tareq SM, Masum EH, Bhattacharjee R. Evaluation of antinociceptive, in-vivo \& in-vitro anti-inflammatory activity of ethanolic extract of Curcuma zedoaria rhizome. BMC Complement Altern Med. 2014;14:346.

18. Adeyemi OO, Yetmitan OK, Taiwo AE. Neurosedative and muscle relaxant activities of ethyl acetate extract of Baphia nitida AFZEL. J Ethnopharmacol. 2006;106:312-6.

19. File SE, Wardill AG. The reliability of the hole-board apparatus. Psychopharmacologia. 1975;44:47-51.

20. Yemitan OK, Ajibade AM, Adeyemi OO. Anticonvulsant activity of Dalbergia saxatilis. Nigerian. J Neurosci. 2001;4:33-40.

21. Dhara AK, Pal S, Nag Chaudhuri AK. Psychopharmacological studies on Tragia involucrate root extract. Phytother Res. 2002;16:326-30.

22. Raju GS, Moghal MMR, Hossain MS, Hassan MM, Billah MM, Ahamed SK, Rana SMM. Assessment of pharmacological activities of two medicinal plant of Bangladesh: Launaea Sarmentosa and Aegialitis Rotundifolia roxb in the management of pain, pyrexia and inflammation. Biol Res. 2014;47:55.

23. Ahmed F, Hossain MH, Rahman AA, Shahid IZ. Antinociceptive and sedative effects of the bark of Cerbera odollam Gaertn. Orient Pharm Exp Med. 2006; 6:344-8.

24. IDG D, Nakamura M, Ferreira SH. Participation Of the sympathetic system in acetic acid-induced writhing in mice. Braz J Med Biol Res. 1988;21:341-3.

25. Derardt R, Jongney S, Delvalcee F, Falhout M. Release Of prostaglandins E and $F$ in an algogenic reaction and its inhibition. Eur J Pharmacol. 1980;51: $17-24$.

26. Zakaria ZA, Gani ZDF. Antinociceptive, anti-inflammatory, and antipyretic properties of an aqueous extract of Dicranopteris Linearis leaves in experimental animal models. J Nat Med. 2008:62:179-87.

27. Kim HP, Son KH, Chang HW, Kang SS. Anti-inflammatory plant flavonoids and cellular action mechanism. J Pharmacol Sci. 2004:96:229-45.

28. Hunskaar S, Fasmer OB, Hole K. Formalin test in mice, a useful technique for evaluating mild analgesia. J Neurosci Methods. 1986;14:69-76.

29. Basak A, Uddin MMN, Sarwar MS, Mohiuddin M, Dewan SMR, Shahriar M, Islam MS. Exploration of analgesic activity of the Ethanolic extract of Erythrina variegate bark. J Therm Anal. 2014;2:37-42.

30. Bhowmick R, Sarwar MS, Dewan SMR, Das A, Das B, Uddin MMN, Islam MS, Islam MS. In vivo analgesic, antipyretic, and anti-inflammatory potential in
Swiss albino mice and in vitro thrombolytic activity of hydroalcoholic extract from Litsea glutinosa leaves. Biol Res. 2014;47:56.

31. Rajnarayana K, Reddy MS, Chaluvadi MR, Krishna DR. Biflavonoids classification, pharmacological, biochemical effects and therapeutic potential. IJP. 2001;33:2-16.

32. Ramesh M, Rao AV, Prabhakar MC, Rao CS, Muralidhar N, Reddy BM. Antinociceptive and anti-inflammatory activity of a flavonoid isolated from Caralluma attenuata. J Ethnopharmacol. 1998;62:63-6.

33. Brown JE, Evans CAR. Luteo-rich artichoke extract protects low density lipoprotein from oxidation in vitro. Free Radic Res. 1998:29:247-55.

34. Domschke K, Zwanzger P. GABAergic and endocannabinoid dysfunction in anxiety - future therapeutic targets? Curr Pharm Des. 2008;14:3508-17.

35. Takeda H, Tsuji M, Matsumiya T. Changes in head-dipping behavior in the hole-board test reflect the anxiogenic and/or anxiolytic state in mice. Eur J Pharmacol. 1998;350:21-9.

36. Barua CC, Roy JD, Buraguohain B, Barua AG, Borah P, Lahkar M. Anxiolytic effect of hydroethanolic extract of Drymasia cordata L wild. IJEB. 2009;47: 969-73.

37. Pellow S, Chopin P, File SE, Briley M. Validation of open: closed arm entries in an elevated plus-maze as a measure of anxiety in the rat. J Neurosci Meth. 1985:14:149-67.

38. Pellow S, File SE. Anxiolytic and anxiogenic drug effects on exploratory activity in an elevated plus-maze: a novel test of anxiety in the rat. Pharmaco Biochem Be. 1986;24:525-9.

39. Bilkei-Gorzó A, Gyertyán I. Some doubts about the basic concept of the hole-board test. Neurobiology. 1996;4:405-15.

40. Carlini EA. Plants and the central nervous system. Pharmacol Biochem Behav. 2003;75:501-12.

41. Dhawan K, Kumar S, Sharma A. Anti-anxiety studies on extracts of Passiflora incarnata Linneaus. J Ethnopharmacol. 2001;78:165-70.

42. Houghton PJ. The scientific basis for the reputed activity of valerian. JPP 1999:51:505-12.

\section{Submit your manuscript to a SpringerOpen ${ }^{\circ}$ journal and benefit from:}

- Convenient online submission

- Rigorous peer review

- Open access: articles freely available online

- High visibility within the field

- Retaining the copyright to your article

Submit your next manuscript at springeropen.com 